appeared-for example, that on the glycogen storage diseases, galactosæmia and the chemical differences between the hrmoglobin variants. The present volume is thus much more than a new edition of Dr. Harris's previous book. It is a good deal longer and well up to date. The chapters deal in succession with a historical sketch, simple genetics, the metabolism of amino-acids and of carbohydrates, the abnormal hrmoglobins, the blood groups, plasma proteins, miscellaneous conditions and the problem of gene action. The last chapter is in many ways the weakest, though it is undoubtedly the most difficult subject to handle. The other chapters are all of an even and high standard. In matters of fact the book is remarkably accurate ; in matters of interpretation it is lucid and well balanced.

The author has somewhat cramped his style by omitting most of the subjects which are speculative, poorly understood, or which cannot be given a firm chemical basis. For example, little mention is made of favism, or of the ability to taste phenylthiocarbamide, or to smell hydrogen cyanide. Population genetics is only briefly treated. This gives the reader the impression of a neatly ordered but restricted field, and the book is therefore less stimulating than it might have been if some of the more provocative themes had been included.

One of the most encouraging aspects of the work described here is the remarkable possibility of cure of the symptoms of some of the inherited diseases. This emphasizes the point that whatever the eugenic problems of our remote descendants, the challenge of our own time is primarily a therapeutic one.

It is a pleasure to handle a book which is so well printed and well bound. The format is the Cambridge University Press's best-well-spaced type on good paper, with contrasting founts for genetic symbols, and clear uncramped figures. The index is reasonably full. It is very well worth the price, and should be in the library of every department of genetics.

P. H. A. SNEATH

\section{COTTON AND GENETICS}

\section{The Application of Genetics to Cotton Improve-} ment

By Sir Joseph Hutchinson. Pp. viii + 87. (Cambridge : At the University Press, 1959. Published in association with the Empire Cotton Growing Corporation.) 15s. net.

7 HIS slim volume of eighty-six pages is based on a number of lectures given by Sir Joseph Hutchinson at the North Carolina State College, with some additions from recent work at the Namulonge Station, of which he was director.

The comprehensive title of the book is scarcely applicable to the restricted range of topics discussed. The reader is led to expect a scholarly appraisal of the methods employed and results obtained in other countries and by other workers. He will be dis appointed.

The work is divided into six sections, which deal respectively with cotton relatives, the origin and spread of the Old World cottons, the origin and spread of New World cottons, the pattern of evolution in cotton-breeding systems, and the improvement of African cottons.
Discussion of problems implied by the title has to be confined within the limits of forty pages. This must be the author's excuse for a mode of treatment lacking in historical perspective, and which promulgates numerous one-sided opinions on questions still acutely controversial.

Much space is given to a discussion of the theory of the recent origin of the New World tetraploid cottons put forward by the author and his colleagues, R. A. Silow and S. G. Stephens. When first put forward in 1947, this theory was greeted with almost unanimous incredulity. The author now summarizes recent cytological and archæological evidence which at last consigns the theory to respectable burial, although he does not formally reject it himself.

The work of Manning and Sir Joseph Hutchinson on the response of Uganda cotton to selection is described. It is shown that by using a selection index in relatively inbred material, a yield advance of the order of 4 per cent per annum was achieved over eight generations of selection.

This technique is important enough to find a place in cotton breeding, but will probably not come into general use unless it can be combined with the mass pedigree system, and with the recent extensions and modifications of this used by Knight in the Sudan. These comprise selfing alternated with panmixis; transfer of genes, and transfer of gene complexes by alternate generations of back crossing and selfing.

Nowhere is it stated that the increase in yield obtained in Uganda was in a cotton with the minute yield of $1,000 \mathrm{lb}$. of seed cotton per acre-approximately one-third of that currently obtained in more favoured countries.

The references to breeding policy in Egypt are unfair and misleading. The brilliant work of Balls and his colleagues in Egypt in almost every branch of science bearing on both yield and quality has been a source of inspiration to cotton workers for nearly a half-century. To omit the name of the inventor of cotton technology is inexcusable; to misrepresent his policy is both mischievous and irresponsible.

It is clear that Balls was never unmindful of either yield or quality. He has written books on both subjects. He tried to strike a balance between the two; he "bred to dollars". Although it receives no mention, the work of Hancock, who subjected hundreds of progeny samples to a small-scale spinning test both for the direct evaluation of quality and for an assessment of genetical purity, is of far-reaching importance since it concerns the very future of cotton as an agricultural crop.

Peruvian workers will note with raised eyebrows the statement that Peruvian Tanguis is "fairly primitive by the standard of most cotton growing countries, being a perennial". In point of fact Tanguis has a low node number, and is no more a perennial than Sea Island, Upland or Egyptian cotton. Far from being primitive it is a highly selected and productive cotton much appreciated on the world market.

Apart from these criticisms, and others for which space is lacking, the book contains much valuable information on the development and evolution of cultivated cottons. It is authoritative when the author refers to material well known to him, and it brings up to date the account given by him and his colleagues in their well-known work "The Evolution of Gossypium".
S. C. HarLand 